
cancer cells and preferentially kills

SUBJECT AREAS: MEDICAL RESEARCH

STEM CELLS

CANCER

CELL BIOLOGY

Received

13 October 2011

Accepted

2 March 2012

Published

12 April 2012

Correspondence and requests for materials should be addressed to H.P. (park001@inha. ac.kr) \title{
cancer stem cells
}

\author{
Chang W. Song' ${ }^{\text {, Hyemi Lee }}{ }^{2}$, Ruud P. M. Dings ${ }^{3}$, Brent Williams' ${ }^{1}$, John Powers' ${ }^{1}$ Troy Dos Santos' \\ Bo-Hwa Choi ${ }^{2} \&$ Heon Joo Park ${ }^{1,2}$
}

'Radiobiology Laboratory, Department of Therapeutic Radiology-Radiation Oncology, University of Minnesota Medical School, Minneapolis, MN. U.S.A, ${ }^{2}$ Department of Microbiology, Center for Advanced Medical Education by BK2 1 Project, College of Medicine, Inha University, Incheon, Korea, ${ }^{3}$ Departments of Biochemistry, Molecular Biology and Biophysics, University of Minnesota, Minneapolis, MN. U.S.A.

The anti-cancer effects of metformin, the most widely used drug for type 2 diabetes, alone or in combination with ionizing radiation were studied with MCF-7 human breast cancer cells and FSaII mouse fibrosarcoma cells. Clinically achievable concentrations of metformin caused significant clonogenic death in cancer cells. Importantly, metformin was preferentially cytotoxic to cancer stem cells relative to non-cancer stem cells. Metformin increased the radiosensitivity of cancer cells in vitro, and significantly enhanced the radiation-induced growth delay of FSaII tumors (s.c.) in the legs of $\mathrm{C} 3 \mathrm{H}$ mice. Both metformin and ionizing radiation activated AMPK leading to inactivation of mTOR and suppression of its downstream effectors such as $\mathrm{S} 6 \mathrm{~K} 1$ and 4EBP1, a crucial signaling pathway for proliferation and survival of cancer cells, in vitro as well as in the in vivo tumors. Conclusion: Metformin kills and radiosensitizes cancer cells and eradicates radioresistant cancer stem cells by activating AMPK and suppressing mTOR.

M etformin (1,1-dimethylbiguanide hydrochloride) is the most widely used drug to treat type 2 diabetic patients. Metformin reduces blood glucose levels by suppressing gluconeogenesis in the liver and increasing glucose uptake by skeletal muscle ${ }^{1-3}$. Metformin decreases blood insulin levels, increases insulin sensitivity, suppresses synthesis of proteins, fatty acids and cholesterol, and increases free fatty acid utilization $^{1-3}$. In addition, metformin has been shown in the last several years to possess strong anti-cancer effects $^{3-7}$. Use of the drug by type 2 diabetic patients significantly suppressed development of cancers in breast ${ }^{8}$, pancreas ${ }^{9}$, and lung ${ }^{10}$, while diminishing cancer-related mortality. Furthermore, the response of diabetic patients with breast cancer to neoadjuvant chemotherapy was markedly better in those treated with metformin rather than other anti-diabetic drugs ${ }^{11}$. In a number of recent preclinical studies, metformin reduced proliferation of cancer cells and induced apoptotic and clonogenic death of cancer cells in vitro ${ }^{4,12-15}$, caused cell cycle arrest ${ }^{13,15}$ and reduced incidence and growth of experimental tumors in vivo ${ }^{16,17}$. These impressive epidemiological and preclinical results led to the recent commencement of several clinical trials evaluating the anti-cancer properties of metformin in combination with conventional chemotherapeutic drugs ${ }^{3-6}$.

The PTEN/PI3K/Akt/mTOR signaling pathway plays a central role in survival and proliferation of cancer cells $^{18-23}$. This pathway is frequently mutated in cancer cells, leading to dysregulation of cell proliferation, differentiation, and survival. Metformin disrupts mitochondrial respiration leading to an imbalance of the AMP:ATP ratio. Increase in the level of AMP relative to ATP activates 5' AMP-activated protein kinase (AMPK), which then suppresses the activity of $\mathrm{mTOR}^{12-17,24}$. Therefore, suppression of $\mathrm{mTOR}$ through AMPK activation is believed to constitute the major mechanism underlying the anti-cancer activities of metfor$\min ^{12-17,21,22}$. Metformin has also been reported to directly inactivate mTOR in certain cell lines ${ }^{3}$. It has been reported recently that ionizing radiation activates $\mathrm{AMPK}^{25-27}$, and that metformin enhances the radiationinduced AMPK activation and cancer cell death ${ }^{25}$. Metformin has also been demonstrated to amplify chemotherapy-induced AMPK activation ${ }^{24}$.

Recent evidence unequivocally indicates that a small proportion of cells in human cancers are cancer stem cells (CSCs) (also termed tumor-initiating cells) ${ }^{28-31}$, and CSCs are both chemoresistant ${ }^{31-35}$ and radioresistant ${ }^{35-38}$ compared with non-cancer stem cells (non-CSCs). Importantly, it has been reported that metformin markedly 
improved the response of human tumor xenografts to conventional chemotherapy drugs by eradicating CSCs in the tumors ${ }^{39-41}$.

In the present report, we show that metformin is potentially effective to enhance the response of cancers to radiotherapy by killing cancer cells preferentially CSCs, and by radiosensitizing cancer cells. Our preliminary results have previously been reported ${ }^{42,43}$.

\section{Results}

Metformin is cytotoxic to cancer cells. Metformin reduced the clonogenic survival of FSaII mouse fibrosarcoma cells and MCF-7 human breast cancer cells in dose and time-dependent manner as shown in Fig. 1. In FSaII cells (Fig. 1A), incubation with $1.0 \mathrm{mM}$ metformin for $1 \mathrm{~h}$ reduced the clonogenic survival of cells to $65.1 \%$, and incubation for $24 \mathrm{~h}$ or $48 \mathrm{~h}$ reduced the survival to $49.3 \%$ and $28.7 \%$, respectively. Incubation of MCF-7 cells with $1.0 \mathrm{mM}$ metformin for 24 or $48 \mathrm{~h}$ decreased the cell survival to $81.7 \%$ and $71.0 \%$, respectively (Fig. 1B). We investigated the effects of a longterm exposure of cells to clinically relevant concentrations of metformin $(6-30 \mu \mathrm{M})^{15,22}$. on the survival of cancer cells. Figure $1 \mathrm{C}$ shows that culturing FSaII cell in media containing $5 \mu \mathrm{M}$ metformin reduced the clonogenic survival to $66.4 \%$, and culturing FSaII and MCF-7 cells with $30 \mu \mathrm{M}$ metformin decreased the survival to $64.1 \%$ and $71.9 \%$ respectively. When cells were cultured in the presence of metformin in the above mentioned studies, the size

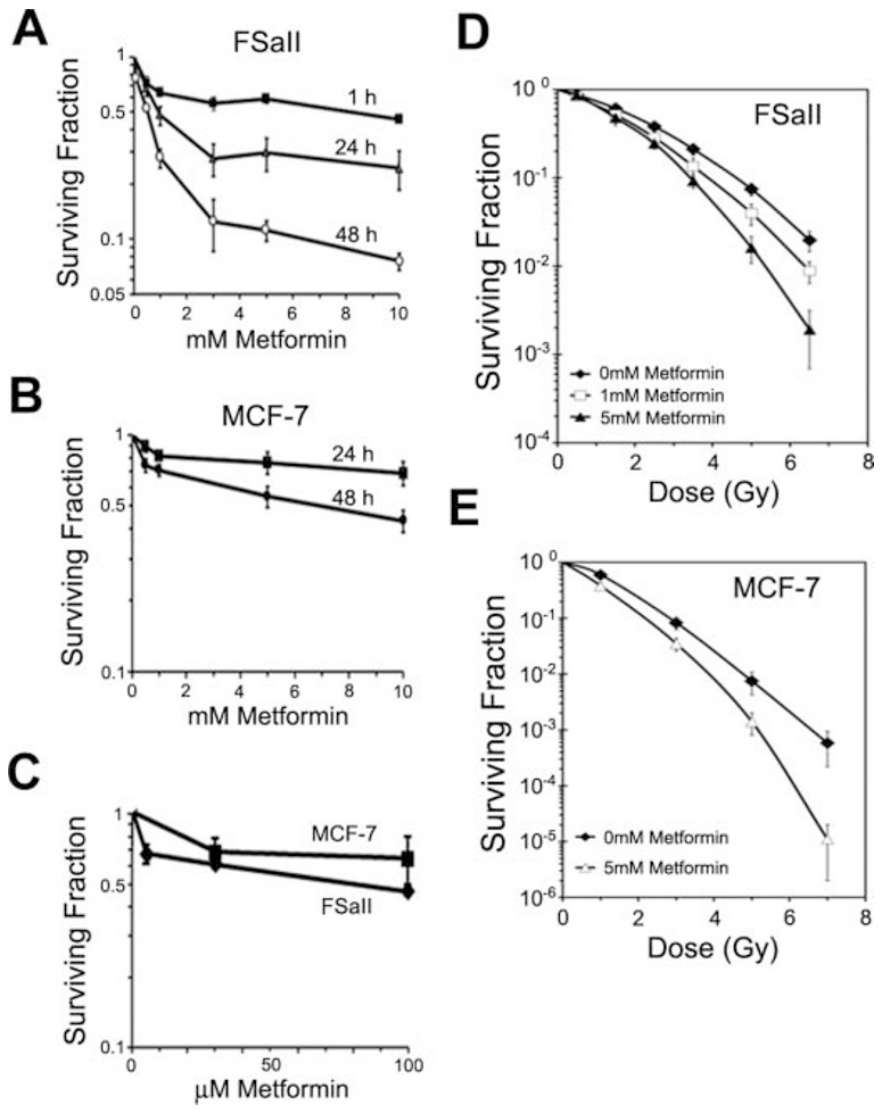

Figure 1 Clonogenic death of FSaII and MCF-7 cells treated with metformin alone or with radiation. (A, B) Cells were incubated for 1-48 h with $0.5-10 \mathrm{mM}$ metformin and the clonogenic survival was determined. (C) Cells were cultured in media containing 5-100 $\mu \mathrm{M}$ of metformin for 10 days for FSaII cells and 20 days for MCF-7 days. (D, E) Cells were incubated with 1 or $5 \mathrm{mM}$ metformin for $24 \mathrm{~h}$, irradiated with various doses of X-rays, further incubated with metformin for $24 \mathrm{~h}$ and then the clonogenic survival was determined. The radiation survival curves were normalized for the cell death caused by metformin alone. All data points are means of $5-7$ independent experiments \pm 1 S.E. of resultant colonies and the cell density in the colonies were found to be reduced as compared with the colonies formed in regular medium. It was thus clear that metformin not only killed cancer cells so that the number of colonies formed were reduced, but it also suppressed the proliferation of surviving cells. We also studied whether metformin causes apoptotic death by flow cytometric determination of sub-G1 cells, annexing $\mathrm{V}$ staining and Western blot analysis of PARP and caspase- 3 cleavage. The incubation for $48 \mathrm{~h}$ with 1-5 mM metformin caused little apoptosis in both MCF-7 and FSaII cells (see Supplementary Fig. S1 online). It thus appeared that apoptotic death did not contribute significantly to the total cell death, i.e. clonogenic cell death, caused by metformin in the present study.

Metformin sensitizes cancer cells to radiation. The radiation survival curves of FSaII and MCF-7 cells treated with metformin for $24 \mathrm{~h}$ before and $24 \mathrm{~h}$ after irradiation were steeper than the radiation survival curves of control cells (Figs. 1D and E). The radiosensitization caused by metformin was statistically significant at radiation doses higher than 3 Gy $(P<0.05)$.

Metformin and irradiation activate AMPK and suppress mTOR, S6K1 and 4EBP1. Figure 2A shows that, in MCF-7 cells incubated with $5 \mathrm{mM}$ metformin, the levels of p-AMPK gradually increased becoming significant after incubation for $16 \mathrm{~h}$ whereas the levels of p-mTOR and its downstream targets $\mathrm{p}$-S6K1 and p-4EBP1 decreased after incubation with $5 \mathrm{mM}$ metformin for $24 \mathrm{~h}$. The levels of p-ACC, a substrate of p-AMPK, also increased as a result of activation of AMPK. These changes in the signals were further amplified when the incubation with $5 \mathrm{mM}$ metformin was prolonged to $48 \mathrm{~h}$. Irradiation of MCF-7 cells with 4 Gy gradually increased $\mathrm{p}$-AMPK levels and slightly decreased the levels of $\mathrm{p}$ mTOR, p-S6K1 and p-4EBP1 from $16 \mathrm{~h}$ post-irradiation. The levels of p-AMPK, p-mTOR, p-S6K1 and p-4EBP1 at $48 \mathrm{~h}$ after irradiation were almost similar to those at $16 \mathrm{~h}$ post-irradiation (Fig. 2A). As shown in Fig. 2B, the treatment of MCF-7 cells for $48 \mathrm{~h}$ with 1 or $5 \mathrm{mM}$ metformin in combination with $4 \mathrm{~Gy}$ irradiation was far more effective than metformin or irradiation alone to increase p-AMPK and p-ACC and to decrease p-mTOR, p-S6K1, and p-4EBP1. Similar results were observed with FSaII cells (Fig. 2C): incubation with $1 \mathrm{mM}$ metformin for 24-48 h increased p-AMPK and p-ACC levels and decreased p-mTOR, p-S6K1 and p4EBP1 levels, and the combination of metformin with irradiation were far more effective than metformin or irradiation alone in activating AMPK and decreasing the phosphorylation of mTOR, S6K1 and 4EBP1. Detailed analysis on the changes in p-AMPK and p-mTOR in MCF-7 cells caused by metformin alone, radiation alone and combined are shown in Supplementary Fig. S2 online.

Inhibition of AMPK reduces the cytotoxic and radiosensitizing effect of metformin. Transfection of MCF-7 and FSaII cells with siRNA for AMPK markedly suppressed the AMPK level (Fig. 3A). The metformin-induced cell death (Fig. 3B) and the metformininduced radiosensitization (Fig. 3C) were also significantly reduced by the transfection of the cells with AMPK siRNA.

Metformin is preferentially toxic to CSCs or CS-like cells relative to non-CSCs. It is well established that CSCs of human breast cancer cells such as MCF-7 cells are characterized with $\mathrm{CD} 44^{\text {high }} / \mathrm{CD} 24^{\text {low }}$ surface markers ${ }^{28,31,37,39-41,44}$. In a representative experiment (Fig. 4A), $2.78 \%$ of MCF-7 cells were CD $44^{\text {high }} / \mathrm{CD} 24^{\text {low }}$ cells, i.e. CSCs, and a $48 \mathrm{~h}$ treatment with $1 \mathrm{mM}$ or $5 \mathrm{mM}$ metformin reduced the fraction of CD $44^{\text {high }} / \mathrm{CD} 24^{\text {low }}$ cells to $2.20 \%$ and $1.29 \%$, respectively. The results of 7 experiments are summarized in Fig. 4B. The fraction of $\mathrm{CD} 44^{\text {high }} / \mathrm{CD} 24^{\text {low }}$ cells before treatment was $3.4 \%$ and the fraction of $\mathrm{CD} 44^{\text {high }} / \mathrm{CD} 24^{\text {low }}$ cells in the surviving cells after $48 \mathrm{~h}$ metformin treatment decreased in dose-dependent manner. For example, the fraction of CD $44^{\text {high }} / \mathrm{CD} 24^{\text {low }}$ cells in the cell population which 
A

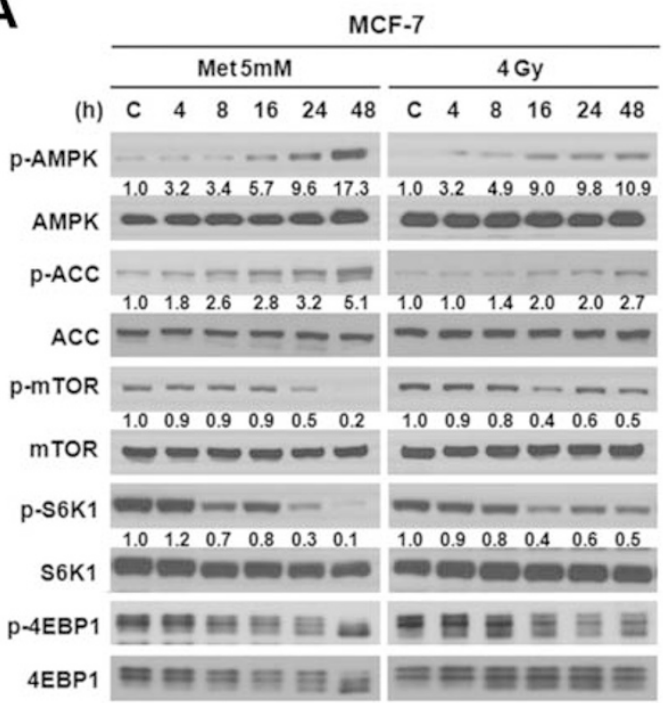

B

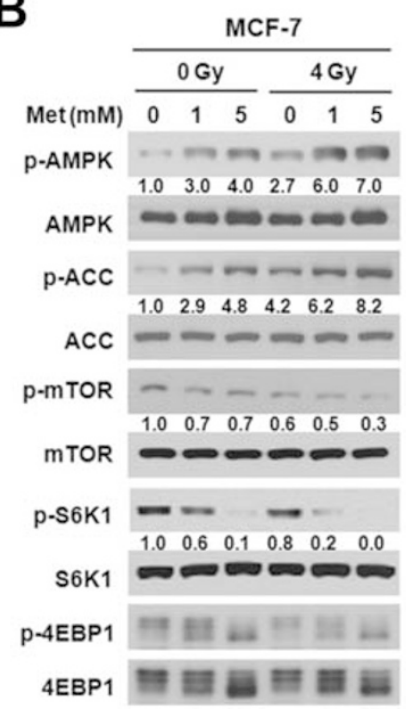

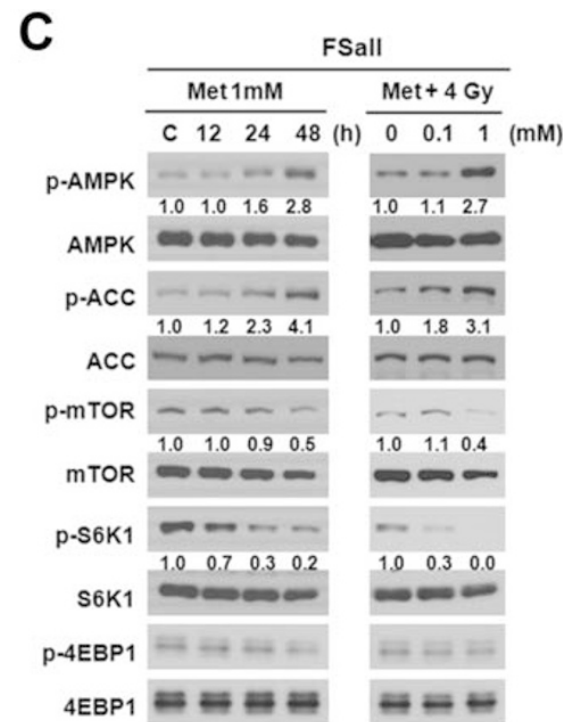

Figure $2 \mid$ Western blotting for the effect of metformin, 4 Gy irradiation or combined on the signals associated with AMPK/mTOR pathway in MCF-7 and FSaII cells. Whole cell lysates were prepared and Western blot analysis was conducted using anti-p-AMPK, -AMPK, -p-ACC, -ACC, -p-mTOR, -mTOR, -p-S6K1, -S6K1, -p-4EBP1 and -4EBP1 antibodies. Experiments were repeated 4-5 times and the representative results are shown. The numbers under each blot are intensity of the blot relative to that of untreated control.

survived the $48 \mathrm{~h}$ treatment with $1 \mathrm{mM}$ metformin was only $2.0 \%$ $(P<0.05)$.

It has been shown that CSCs in various cancers express high-level of aldehyde dehydrogenase (ALDH1) activity, and thus ALDH1positive CSCs can be isolated by flow cytometry ${ }^{44-46}$. Representative results of the effect of metformin on the proportion of ALDH1-positive cells, putative CSCs or CS-like cells, in the FSaII cells are shown in Fig. 4C. The proportion of ALDH1-positive FSaII cells was initially $2.72 \%$, and it decreased to 1.66 and $0.80 \%$ after an $48 \mathrm{~h}$ incubation with 0.1 and $1 \mathrm{mM}$ metformin, respectively. The means of 5-7 determinations are shown in Fig. 4D. Before the treatment, $1.92 \%$ of FSaII cells were ALDH1-positive, and incubation with $0.1 \mathrm{mM}$ metformin for $48 \mathrm{~h}$ reduced the proportions of ALDH1-positive cells in the surviving cells to $1.08 \%(P<0.05)$.

The activities of ATP-binding cassette $(\mathrm{ABC})$ transporters including the ABCG2 transporter are markedly elevated in $\mathrm{CSCs}^{32}$. Therefore, when cells are incubated with certain dyes such as the fluorescent Hoechst 33342, CSCs expel the dye whereas non-CSCs do not, thus making it possible to identify CSCs as side population (SP) cells by flow cytometry ${ }^{44,47}$. Representative data on the metformin-induced changes in the fraction of SP cells (putative CSCs) of FSaII cells are shown in Fig. 4E: proportion of SP cells decreased from $2.15 \%$ in the control to $0.88 \%$ after a $48 \mathrm{~h}$ incubation with $5 \mathrm{mM}$ metformin. Given that $\mathrm{CD} 44^{\text {high }} / \mathrm{CD} 24^{\text {low }}$ cells are CSCs of breast cancer ${ }^{28,31,37,39-41,44}$, and ALDH1-positive cells are putative CSCs or CS-like cells ${ }^{4-46}$ and SP cells are also putative CSCs of many different cancer cell lines ${ }^{44,47}$, the decreases in the proportion of CD44high/ CD24 ${ }^{\text {low }}$ cells, ALDH1-positive cells and SP cells by metformin clearly indicated that metformin is preferentially cytotoxic to CSCs or CS-like cells relative to non-CSCs in MCF-7 and FSaII cells, as observed in other cell lines ${ }^{39-41}$, We have observed similar results in human MIAPaCa-2 pancreatic cancer cells and human A549 human cancer cells ${ }^{42,43}$.

Metformin impedes sphere formation. CSCs grow as spheres (tumor-spheres) upon incubation in non-adherent conditions $\mathrm{s}^{39,40,44}$. When 1,000 MCF-7 cells were incubated for 8 days in metforminfree sphere medium, $44 \pm 3$ spheres with $>50 \mu \mathrm{M}$ diameter were formed while $32 \pm 2$ and $13 \pm 2$ spheres were formed when incubated with $0.1 \mathrm{mM}$ or $0.5 \mathrm{mM}$ metformin, respectively. The numbers of FSaII spheres also declined when cultured with metformin. In addition to the decline in the number of sphere formed, the size of spheres formed upon incubation with $0.1 \mathrm{mM}$ metformin was clearly smaller than those in the medium without metformin (Fig. 5A).

CSCs or CS-like cells are radioresistant. Figure $6 \mathrm{~A}$ shows that, in a representative study, $3.14 \%$ of MCF-7 cells were $\mathrm{CD} 44^{\text {high }} / \mathrm{CD} 24^{\text {low }}$ cells, i.e. CSCs, and irradiation with 3 or 5 Gy followed by a $48 \mathrm{~h}$ incubation increased the fraction of $\mathrm{CD} 44^{\text {high }} / \mathrm{CD} 24^{\text {low }}$ cells to $4.82 \%$ and $6.05 \%$, respectively. Such an increase in the fraction of CD $44^{\text {high }} /$ $\mathrm{CD} 24^{\text {low }}$ cells after irradiation indicated that CSCs are more radioresistant than non-CSCs. Importantly, maintaining MCF-7 cells with $1 \mathrm{mM}$ metformin for $48 \mathrm{~h}$ after irradiation reduced the radiation-induced increase in the fraction of CSCs. The means of 5 experiments (Fig. 6B) showed that $1 \mathrm{mM}$ metformin significantly suppressed the increase in the CSCs fraction caused by 3-7 Gy irradiation in MCF-7 cells. As shown in Fig. 5C, irradiation with 3 or $5 \mathrm{~Gy}$ significantly increased the fractions of ALDH1-positive FSaII cells, and metformin attenuated the radiation-induced increase in the fraction of ALDH1-positive cells.

Metformin enhances the efficacy of radiation to suppress tumor growth. Figure 7A shows that the treatment of $\mathrm{C} 3 \mathrm{H}$ mice bearing FSaII tumors in the hind legs (s.c.) with metformin at $25 \mathrm{mg} / \mathrm{kg}$ twice a day (i.p.) slightly reduce the tumor growth. On the other hand, irradiation of tumors with 20 Gy markedly suppressed the tumor growth starting about 12 days post-irradiation. When host mice were treated with $25 \mathrm{mg}$ metformin/ $\mathrm{kg}$ twice a day, and tumors were irradiated $1 \mathrm{~h}$ after the first metformin treatment, tumor growth was markedly suppressed. Consequently, the days required for 4-fold increase in tumor volume were $17 \pm 3$ days after $20 \mathrm{~Gy}$ irradiation whereas it was $28 \pm 4$ days after the combined treatment with irradiation and metformin. The difference i.e. 17 v.s. 28 days, was statistically significant $(P<0.001)$. The appearance of skin over the tumors treated with radiation alone and those treated with metformin in combination with radiation were similar.

To reveal whether AMPK/mTOR signaling pathway plays any role in the response of tumors to metformin and irradiation, we investigated the expression of $\mathrm{p}$-AMPK and p-mTOR in the tumors using immunohistological method (Figs. 7B-E). In the FSaII tumors 
A
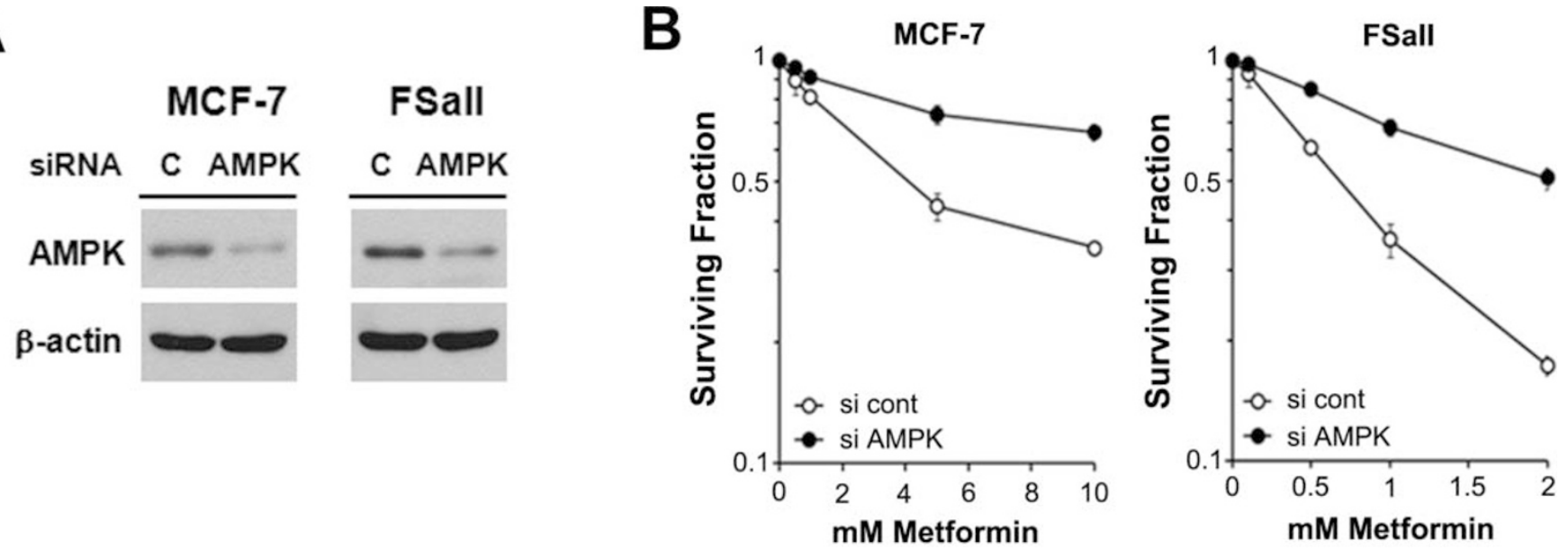

C

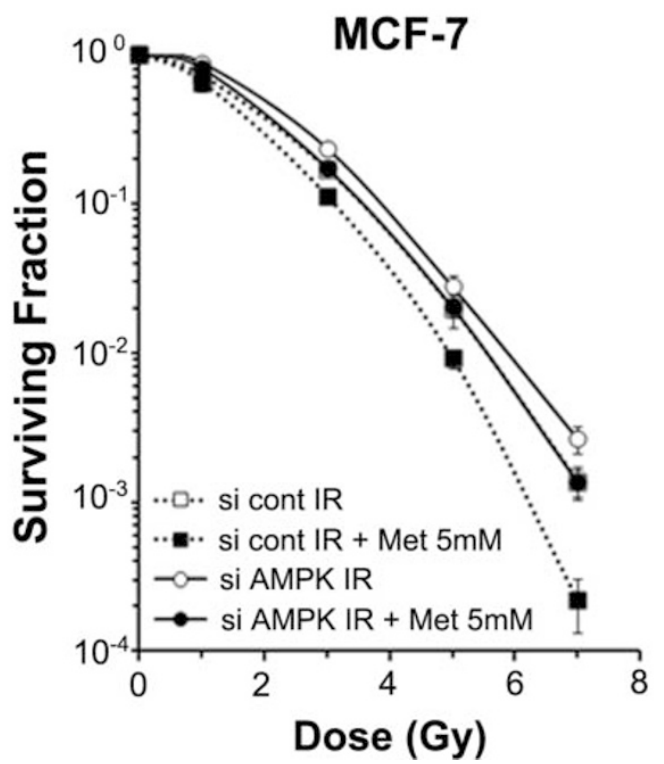

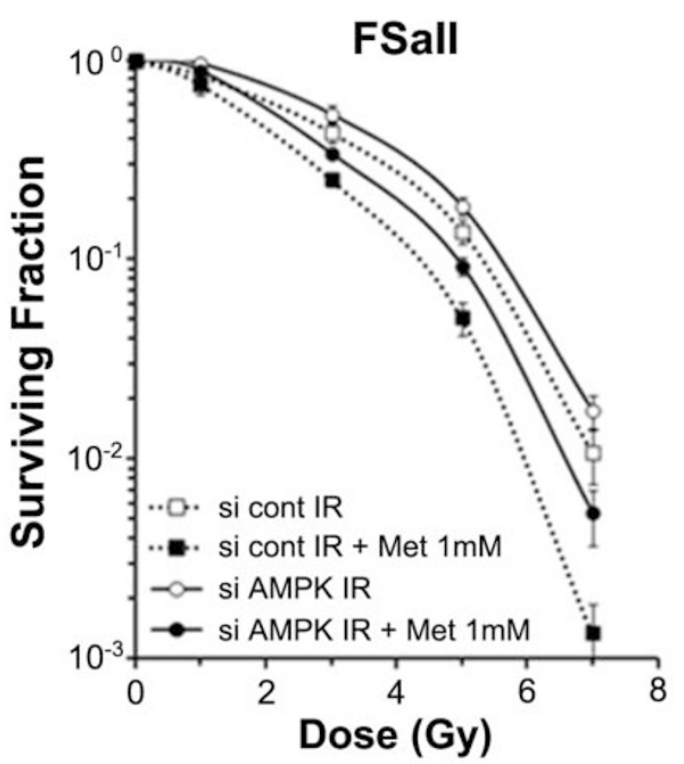

Figure 3 Effects of AMPK siRNA on the cytotoxic and radiosensitizing effects of metformin. (A) Transfection of MCF-7 and FSaII ells with siRNA against AMPK markedly reduced the AMPK levels in the cells. (B) Transfection of cells with AMPK siRNA markedly reduced the clonogenic cell death caused by $48 \mathrm{~h}$ incubation with various concentrations of metformin. (C) Transfection of cells with AMPK siRNA reduced the efficacy of metformin to sensitize the cells to radiation. Cells were incubated with 1 or $5 \mathrm{mM}$ metformin for $24 \mathrm{~h}$, irradiated with various doses of X-rays, further incubated with metformin for $24 \mathrm{~h}$ and then cultured for colony formation. The radiation survival curves were normalized for the cell death caused by metformin alone.

treated with $25 \mathrm{mg}$ metformin/kg twice a day for 6 days, the level of p-AMPK significantly increased. The level of p-AMPK also significantly increased 6 days after 20 Gy irradiation. When tumors were irradiated $1 \mathrm{~h}$ after the first metformin treatment, the increase in $\mathrm{p}$ AMPK expression was more pronounced than that occurred by metformin or irradiation alone (Figs. 7B and C). In contrast to the increase in p-AMPK levels, p-mTOR levels was markedly suppressed by metformin and irradiation alone or combined (Figs. 7D and E). Similar results were obtained with MCF-7 tumors grown in nude mice (see Supplementary Fig. S3 online).

\section{Discussion}

This study has shown that metformin is cytotoxic to cancer cells at clinically achievable concentrations. Importantly metformin was preferentially cytotoxic to CSCs or CS-like cells relative to non-CSCs. Furthermore metformin increased the radiosensitivity of cancer cells in vitro and it markedly enhanced the response of experimental tumors to irradiation suggesting that the anti-diabetic drug metformin is potentially useful to enhance the efficacy of radiotherapy of cancer. Activation of AMPK and suppression of mTOR appeared to play an important role for the cytotoxic and radiosensitizing effect of metformin in vitro as well as in vivo.

Treatment of FSaII and MCF-7 cells with metformin at concentrations as low as $0.5 \mathrm{mM}$ for $1-48 \mathrm{~h}$ significantly reduced clonogenic survival of the cells (Fig. 1). The plasma concentrations of metformin of type 2 diabetic patients treated with metformin are elevated to $6-30 \mu \mathrm{M}$ range $\mathrm{e}^{15,22}$. As shown in Fig. $1 \mathrm{C}$, the long-term incubation of MCF-7 or FSaII cells with media containing 5-30 $\mu \mathrm{M}$ metformin reduced the clonogenic survival of cells by about $30 \%$ (Fig. 1C). In addition to inducing clonogenic death, the prolonged exposure to $5-100 \mu \mathrm{M}$ of metformin markedly reduced the size of colonies formed and decreased the cell density in the colonies (data not shown) indicating that metformin not only kills cancer cells but it also suppresses the proliferation of surviving cancer cells, in agreement with the reports by other investigators ${ }^{14,21}$. The mode of cell death caused by metformin is unknown, but our studies indicated that apoptotic death contribute little to the total clonogenic cell death. It appeared that cells undergo necrotic death rather than apoptosis upon treatment with metformin (see Supplementary Fig. S1 online). Another potentially important feature of metformin was 


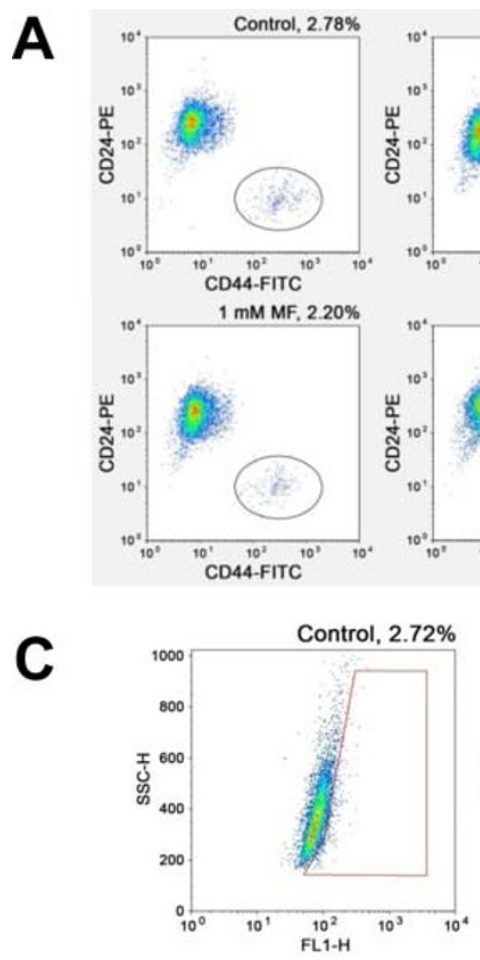

$0.5 \mathrm{mM}$ MF, $2.75 \%$

B

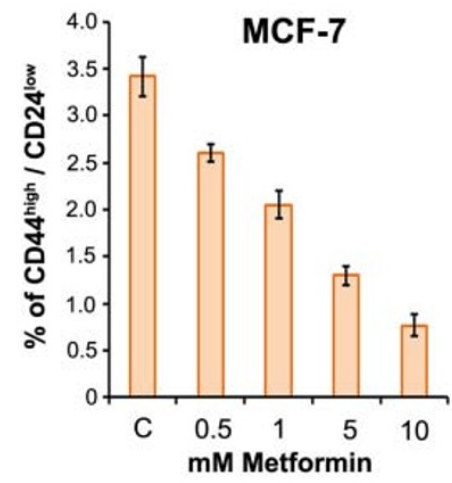

D
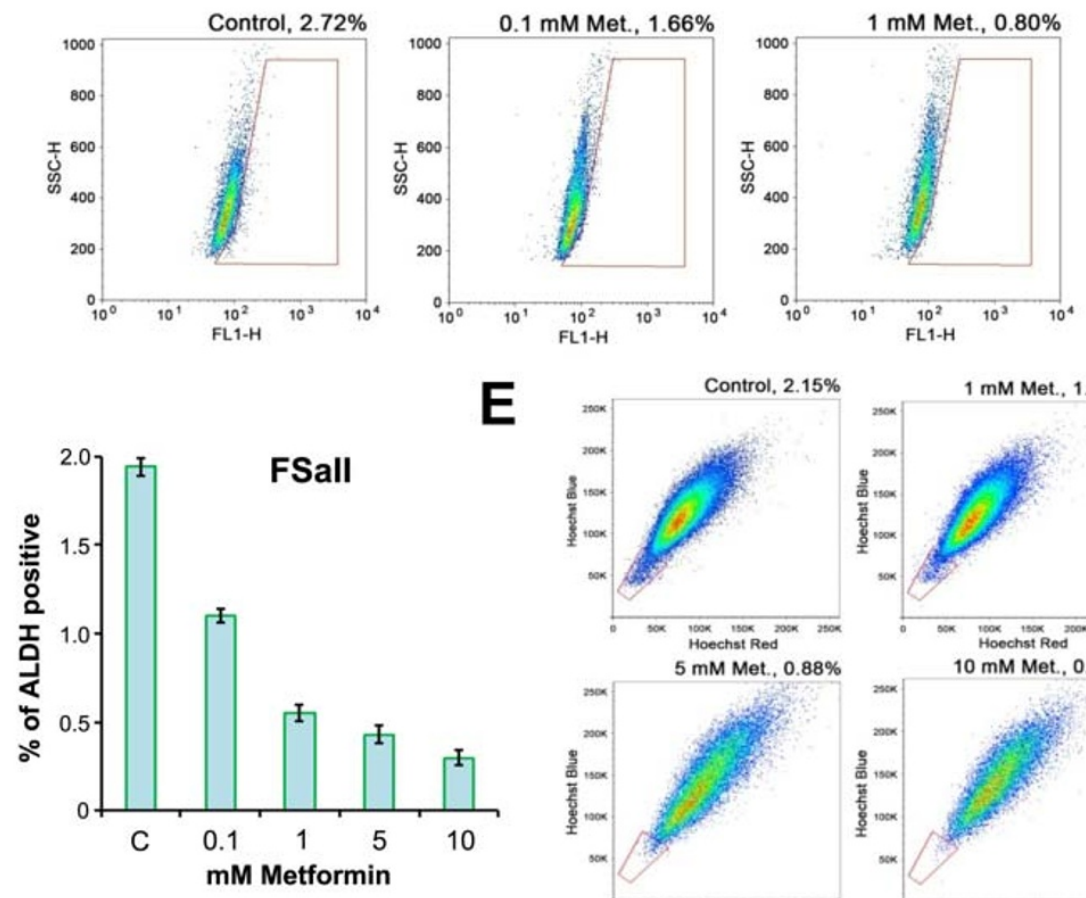

E
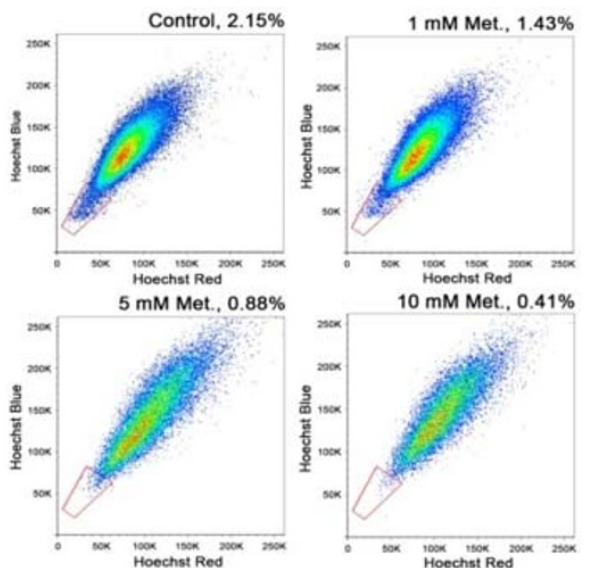

Figure $4 \mid$ Effect of metformin on the CSCs or CS-like cells. Cells were incubated with different concentrations of metformin for $48 \mathrm{~h}$, dispersed to single cells, washed, and the fraction of CSCs or CS-like cells were analyzed. (A) FACS for CD44 $4^{\text {high }} / \mathrm{CD} 24^{\text {low }}$ cells of MCF-7 cells treated with 0.5-5.0 mM metformin for $48 \mathrm{~h}$. (B) $\%$ of CD $44^{\text {high }} / \mathrm{CD} 24^{\text {low }} \mathrm{MCF}-7$ cells in the surviving cells after treating with different concentrations of metformin for $48 \mathrm{~h}$. Means of 7 experiments \pm 1 S.E are shown. The declines in $\%$ of CD $44^{\text {high }} / \mathrm{CD} 24^{\text {low }}$ cells by $0.5-10 \mathrm{mM}$ metformin were statistically significant $(P<0.05)$. (C) FACS for ALDH1-positive FSaII cells treated with metformin for $48 \mathrm{~h}$. (D) \% of ALDH1-positive cells of FSaII cells treated with different concentrations of metformin for $48 \mathrm{~h}$. Means of 5-7 experiments \pm 1 S.E are shown. The declines in $\%$ of ALDH1-positive cells by $0.1-1.0 \mathrm{mM}$ metformin were statistically significant $(P<0.05)$. (E) Changes in \% of SP cells in FSaII cells treated with different concentrations of metformin for 48 h.

that $48 \mathrm{~h}$ treatment of cancer cells with $1 \mathrm{mM}$ or $5 \mathrm{mM}$ metformin significantly increased their radiosensitivity (Fig. 1D).

Increasing evidence indicates that the P13K/Akt/mTOR pathway plays crucial role in the survival and proliferation of cancer cells ${ }^{3-}$ ${ }^{5,18-20}$. Metformin has been shown to inactivate mTOR via activation of AMPK, thereby causing cell cycle arrest, apoptosis, and clonogenic death, and inhibition of tumorigenesis ${ }^{3,5,12-17,21}$. In the present study, in excellent agreement with the previous reports, metformin markedly activated AMPK and inactivated mTOR, thereby decreasing the levels of downstream effectors p-S6K1 and p-4EBP1 in MCF-7 and FSaII cells in vitro (Fig. 2). Importantly, as reported by others ${ }^{25-27}$, irradiation also activated AMPK leading to reduction of $\mathrm{p}-\mathrm{mTOR}$, $\mathrm{p}$ S6K1 and p-4EBP1 in the present study (Fig. 2). Combination of metformin and irradiation was more efficient than either radiation or metformin alone to activate AMPK and inactivate mTOR and its targets S6K1 and 4EBP1 (Figs. 2B and C). Similar to our observation, metformin markedly enhanced the radiation-induced activation of AMPK in cancer cells ${ }^{25}$. However, other investigators reported that ionizing radiation caused $\mathrm{mTOR}$ activation rather than $\mathrm{mTOR}$ inactivation in various cell lines ${ }^{27,48,49}$ particularly in the absence of AMPK activity ${ }^{27}$. In these studies, mTOR activation was observed in 1-6 h after irradiation, while in our study, inactivation of mTOR occurred from $16 \mathrm{~h}$ after irradiation. In a recent study, mTOR was activated for $6 \mathrm{~h}$ after irradiation and then inactivated thereafter ${ }^{50}$. Such an increase in mTOR activity after irradiation may be attributed to radiation-induced activation of $\mathrm{Akt}^{26}$. We may then speculate that mTOR activity is transitorily increased after irradiation, but the increase is eventually subdued as a result of progressive increase in 
A

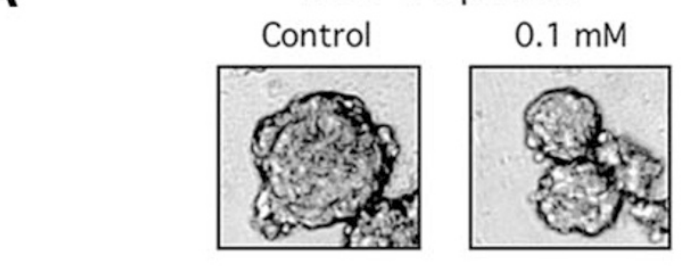

B

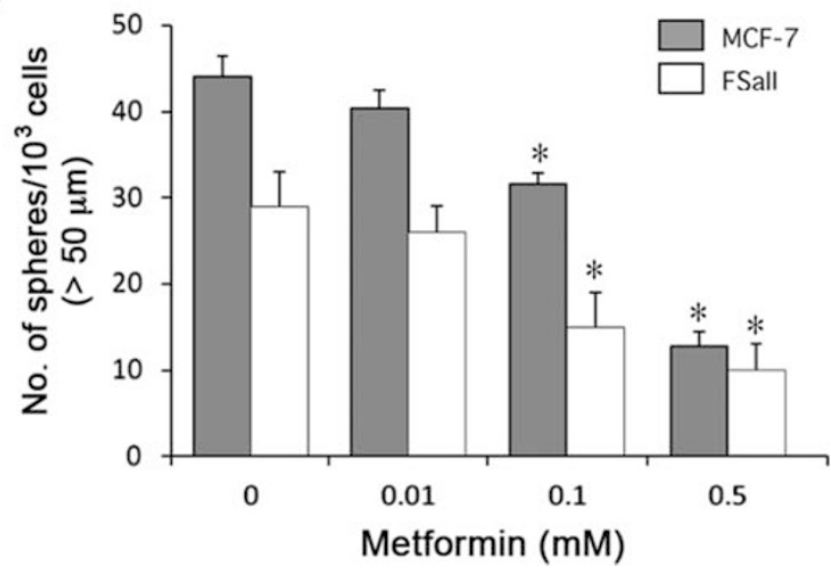

Figure 5 Effect of metformin on the growth of spheres of MCF-7 and FSaII cells. Cells were cultured for 8 days in ultralow attachment wells with sphere media containing different concentrations of metformin. (A) MCF7 spheres grown with or without $0.1 \mathrm{mM}$ metformin. (B) The numbers of sphere with $>50 \mu \mathrm{m}$ in diameter obtained from $10^{3}$ cells. Means of 5 experiments \pm 1 S.E are shown. ${ }^{*} P<0.05$ between control and metformin treated groups.

AMPK activity. These observations are of interest since inhibition of mTOR activity with rapamycin or RAD100 markedly increased the cellular radiosensitivity ${ }^{48,49}$. As shown in Fig. 3, inhibition of AMPK activity with AMPK siRNA significantly reduced the cytotoxic and radiosensitizing effects of metformin against MCF-7 and FSaII cells, in agreement with the report by others ${ }^{24}$. Together, it may be reasonable to conclude that the metformin-induced cell death and radiosensitization of cancer cells (Fig. 1) are caused by the metformininduced activation of AMPK and resultant inactivation of mTOR.

The significant decline in the fraction of CD $44^{\text {high }} / \mathrm{CD} 24^{\text {low }}$ cells, i.e. CSCs, of MCF-7 cells and ALDH1-positive cells and SP cells of FSaII (Fig. 3) by metformin indicated that metformin is preferentially cytotoxic to CSCs or CS-like cells compared with non-CSCs. Our results are in excellent agreement with the recent observations by others that metformin selectively killed CSCs in various cell lines ${ }^{39-41}$. We have previously observed similar results in other human cancer cell lines including MIAPaCa-2 pancreatic cancer and A549 lung cancer cells ${ }^{42,43}$. CSCs have been known to grow as spheres (tumor-spheres) when incubated in non-adherent conditions $\mathrm{s}^{39,40,44}$. Metformin at concentrations as low as $0.01 \mathrm{mM}$ could suppress the number and size of spheres derived from both MCF-7 cells and FSaII cells (Fig. 5) further supporting the conclusion that CSCs or CS-like cells are more vulnerable to metformin than nonCSCs. As pointed out above, inactivation of mTOR may be a major mechanism for the anti-cancer effects of metformin. The PI3K/Akt/ mTOR pathway has been reported to be activated in more aberrant manner in CSCs than non-CSCs ${ }^{18-20,29,30}$ so that CSCs are more sensitive than non-CSCs to suppression of mTOR. Indeed, suppression of Akt or mTOR was preferentially toxic to CSCs relative to non$\mathrm{CSCs}^{19,22,23}$. Therefore, we may conclude that the metformin-induced suppression of mTOR via AMPK activation is more toxic to CSCs or CS-like cells than non-CSCs.
In contrast to the effect of metformin, ionizing radiation increased the relative proportion of CSCs or CSC-like cells (Fig. 6) indicating that CSCs or CS-like are radioresistant as compared with non-CSCs. Other investigators also reported that CSCs were radioresistant ${ }^{35-38}$ although the mechanism for the radioresistance of CSCs has not yet been clearly defined. Importantly, metformin significantly reduced the radiation-induced increase in the fraction of CSCs or CS-like cells (Fig. 6), which may be attributed to metformin-induced death of CSCs or CS-like cells. It is also possible that metformin sensitized CSCs or CS-like cells to radiation. Further studies are needed to reveal this intriguing and potentially important question.

Treatment of mice bearing FSaII tumors (s.c.) in the legs with metformin at $50 \mathrm{mg} / \mathrm{kg} /$ day (i.p.) slightly suppressed the growth of tumors (Fig. 7), in agreement with the reports by others ${ }^{33,51,52}$. Although the inhibition of tumor growth by metformin alone was small in the present study (Fig. 7), the drug markedly enhanced the response of tumors to irradiation. Such a marked suppression of tumor growth by the combined treatment may be attributed, at least in part, to the pronounced suppression of mTOR activity as a result of AMPK activation in the tumor cells (Fig. 7). Based on the results of in vitro studies, we may further speculate that metformin caused death of cancer cells, suppressed the proliferation of cancer cells, radiosensitized cancer cells, and eradicated or radiosensitized CSCs. Further studies are warranted to reveal the exact mechanisms by which metformin causes the remarkable increase in the radioresponse of tumors. The maximum safe dose of metformin for human is $2,550 \mathrm{mg} /$ day for average size person of $60 \mathrm{~kg}^{53}$. In the present study, the dose of metformin given to mouse was $50 \mathrm{mg} / \mathrm{kg} /$ day, which is equivalent to $240 \mathrm{mg} /$ day for $60 \mathrm{~kg}$ person according to a formula suggested by the National Institute of Health (U.S.A.) ${ }^{53}$. Therefore, the dose used for mouse in the present study was only about one-tenth that for the recommended safe dose for human.

It would be of interest to determine the proportion of CSCs in the tumors before and after treatment. The present study on the combined effect of metformin and a large single dose of radiation against tumor is relevant to the current trend of hypofractionated radiotherapy with high-dose per fraction using stereotactic techniques. However, the efficacy of metformin to enhance the response of tumors to conventional fractionated radiotherapy remains to be determined. Nevertheless, our results clearly indicated for the first time that metformin is potentially effective to enhance the efficacy of radiotherapy.

\section{Methods}

Cell lines. FSaII fibrosarcoma cells of C3H mice and MCF-7 human mammary adenocarcinoma cells obtained from the American Type Culture Collection (Manassas, VA) were used. We have previously used FSaII cells for various radiobiological research ${ }^{54}$.

Clonogenic survival of cancer cells. Cells in exponential growth phase were treated with metformin at $37^{\circ} \mathrm{C}$ for various lengths of time. Cells were then washed twice, cultured in drug-free regular medium (10-12 days for FSaII cells and 20 days for MCF7 cells), colonies formed were fixed and stained ${ }^{51}$. The numbers of colonies containing more than 50 cells were counted and the surviving fractions wee calculated.

Effect of metformin on the radiation-induced death of cancer cells. Cells were incubated with metfomin for $24 \mathrm{~h}$ before and $24 \mathrm{~h}$ after irradiation, and their clonogenic survival was determined. Cells treated with metformin for $48 \mathrm{~h}$ without exposure to radiation or those exposed to irradiation only were used as controls. Irradiation of cells were performed with $250 \mathrm{kV}$ orthovoltage X-rays (Philips Medical System).

Effect of AMPK siRNA on the cytotoxic and radiosensitizing effects of metformin. Cells were transfected with AMPK siRNA and then investigated the response of cells to metformin and irradiation alone or combined. siRNA duplexes targeting human AMPK was purchased from Dharmacon (Lafayette, CO). siRNA duplexes targeting mouse AMPK was purchased from Santa Cruz. AccuTarget ${ }^{\mathrm{TM}}$ negative control siRNA (Invitrogen, Carlsbad, CA) was used as a negative control. LipofectAMINE 2000 (Invitrogen) was used to transfect siRNA duplexes at final concentrations of $50 \mathrm{nM}$ according to the manufacturer's recommendations.

Analysis of signaling pathway by Western blot. Cells were lysed, proteins were separated by SDS-polyacrylamide gel electrophoresis (PAGE) and transferred to 

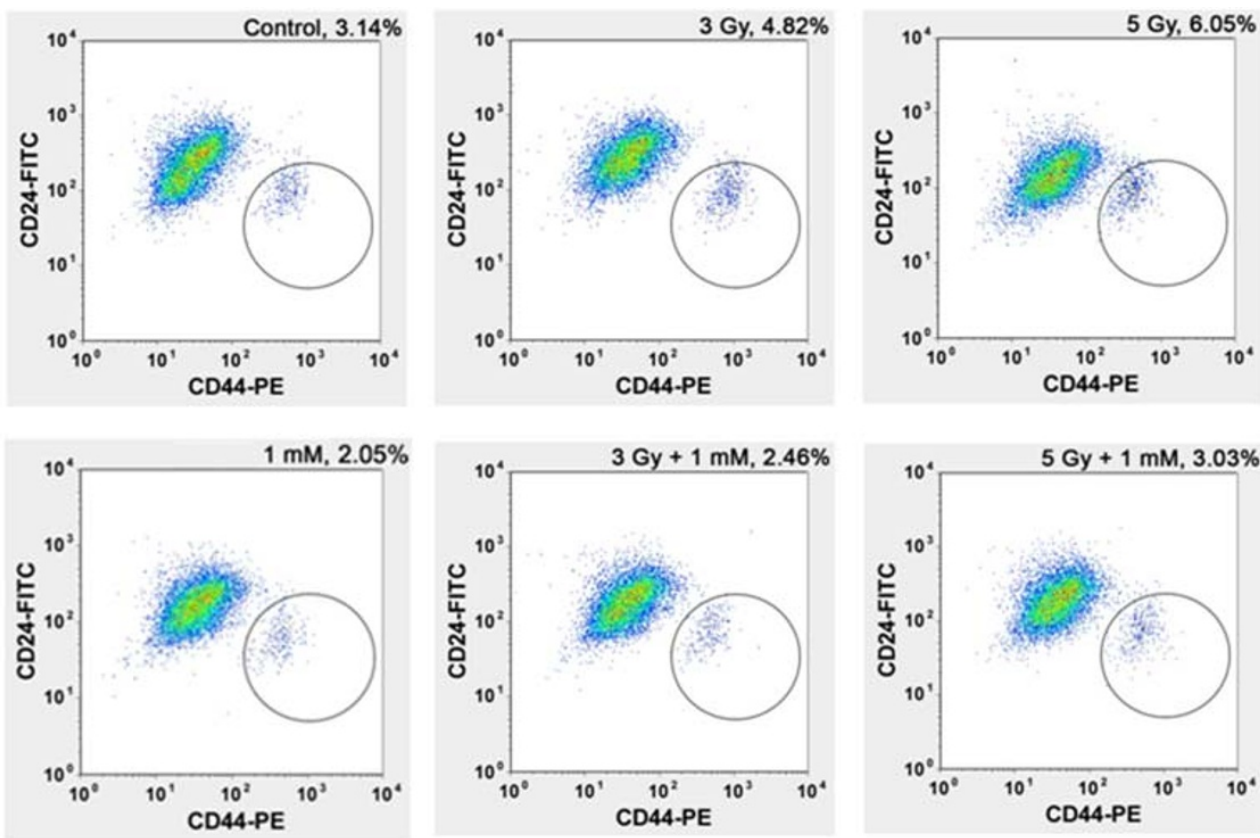

B

MCF-7

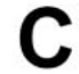

FSall
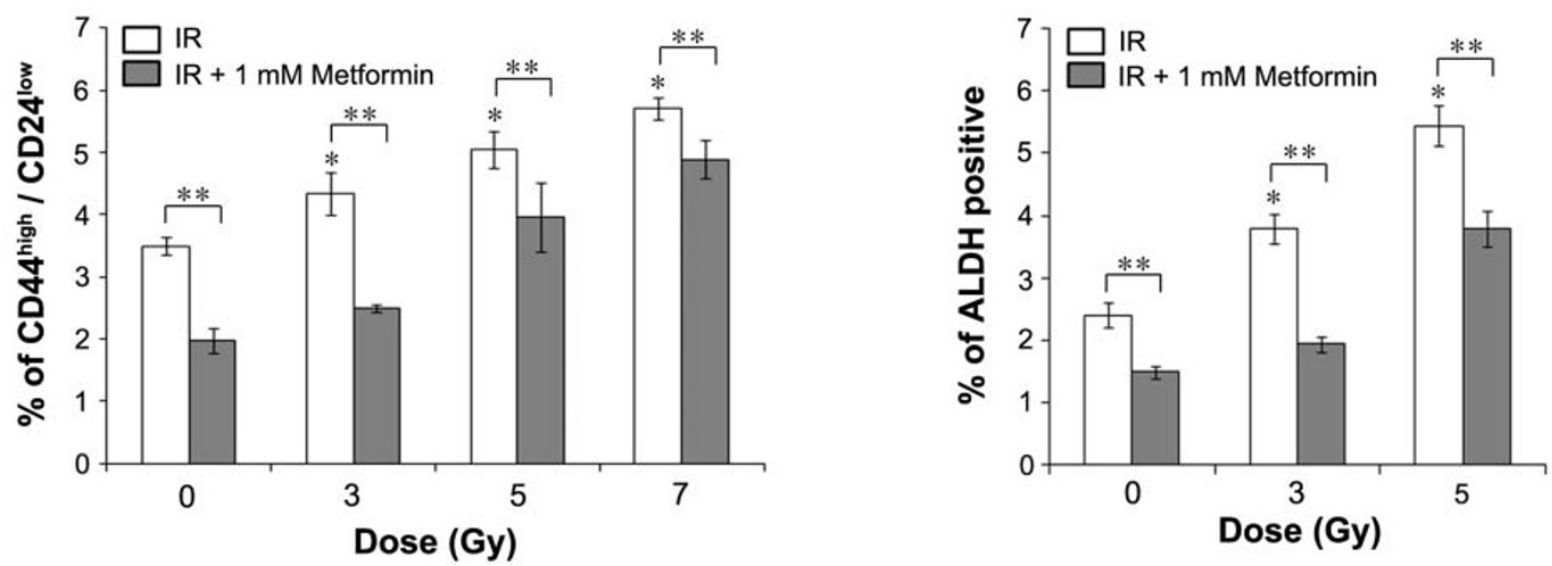

Figure 6 Effects of metformin on the radiosensitivity of CSCs or CS-like cells. (A) MCF-7 cells were irradiated, incubated with or without 1 mM metformin for $48 \mathrm{~h}$ and analyzed for CD $44^{\text {high }} / \mathrm{CD} 24^{\text {low }}$ cells. (B) $\%$ of CD $44^{\text {high }} / \mathrm{CD} 24^{\text {low }}$ MCF-7 cells after irradiation and $48 \mathrm{~h}$ incubation with $1 \mathrm{mM}$ metformin. Means of 5 experiments \pm 1 S.E. ${ }^{*} P<0.05$ for IR-induced increases. ${ }^{* *} P<0.05$ between IR and IR + Metformin. (C) $\%$ of ALDH1-positive FSaII cells after irradiation and $48 \mathrm{~h}$ incubation with $1 \mathrm{mM}$ metformin. Means of 5 experiment \pm 1 S.E. $* P<0.05$ for IR-induced increases. $* * P<0.05$ between IR and IR + 1 mM Metformin groups.

nitrocellulose membranes. The membranes were blocked with $1 \%(\mathrm{v} / \mathrm{v})$ nonfat dry milk in Tris-buffered saline with $0.05 \%$ Tween 20 and incubated with antibodies against proteins of interest(Antibodies against p-AMPK (Thr172), p-ACC (Ser79), p-mTOR (Ser2448), p-S6K1 (Thr389), p-4EBP1(Thr37/46), AMPK, ACC, mTOR, S6K1, 4EBP1 and $\beta$-actin were obtained from Cell Signaling Technology (Beverly, $\mathrm{MA}))^{51}$. The blots were labeled with goat anti-rabbit or anti-mouse IgG conjugated with horseradish peroxidase, and visualized with chemiluminescence (SUPEX, NeuroNex, Korea). The band intensities were measured using ImageJ 1.41 software (NIH, Bethesda, MD)

Effect of metformin on CSCs or CS-like cells. MCF-7 cells. MCF-7 cells were incubated with metformin for 24 or $48 \mathrm{~h}$, enzymatically dispersed into single cells, washed, and suspended in PBS. Cells were next incubated for $20 \mathrm{~min}$ with anti-CD44 antibody (FITC-conjugated 555478, BD Biosciences, Franklin Lakes, N.J.) followed by incubation with phycoerythrine-conjugated anti-CD24 antibody (BioLegend, San Diego, CA) for $20 \mathrm{~min}$ in the dark at $4^{\circ} \mathrm{C}$, washed with PBS containing $1 \%(\mathrm{v} / \mathrm{v})$ FCS, and then $\mathrm{CD} 44^{\text {high }} / \mathrm{CD} 24^{\text {low }}$ cells were identified using flow cytometry ${ }^{37,39,40}$. FSaII cells. The CSCs or CS-like cells of FSaII cells were identified using the Aldefluor assay method and also the Side population assay method ${ }^{44-46}$. Aldefluor assay ${ }^{4-46}$ : FSaII cells were treated with metformin for 24 or $48 \mathrm{~h}$ and washed. The cells were then dispersed into single cells, and the ALDH activity was determined following the manufacturer's instruction (BODIPY-aminoacetaldehyde, Stemcell Technology, Vancouver, Canada). Side population assay: FSaII cells were treated with metformin for 24 or $48 \mathrm{~h}$ and washed. The cells were then dispersed into single cells, incubated with Hoechst 33342 (Sigma, St Louis, MO) at $50 \mu \mathrm{mol} / \mathrm{mL}$ either alone or in combination with the ABC transporter inhibitors verapamil $(50 \mu \mathrm{mol} / \mathrm{mL}$ ) (Sigma, St Louis, MO) and FTC $(10 \mu \mathrm{M})$ for $90 \mathrm{~min}$ at $37^{\circ} \mathrm{C}$. After washing, SP cells were identified using flow cytometry ${ }^{44,46}$.

Effect of metformin on sphere formation. FSaII and MCF-7 cells were plated in sixwell ultralow attachment plates (Corning, Lowell, MA) at a density of 1000 cells/plate in serum-free RPMI medium supplemented with $20 \mathrm{ng} / \mathrm{mL} \mathrm{BGF,} 20 \mathrm{ng} / \mathrm{mL}$ EGF, $5 \mu \mathrm{g} / \mathrm{mL}$ bovine insulin and $2 \%(\mathrm{v} / \mathrm{v}) \mathrm{B} 27$, and containing no or various concentrations of metformin. After incubation for 8 days, the numbers of spheres with diameter $>50 \mu \mathrm{M}$ were counted under a microscope ${ }^{39,40,44}$.

Radiosensitivity of CSCs or CS-like cells. MCF-7 cells or FSaII cells in exponentially growth phase were irradiated and incubated with or without $1 \mathrm{mM}$ metformin for $48 \mathrm{~h}$. The fraction of CD $44^{\text {high }} / \mathrm{CD} 24^{\text {low }}$ cells in MCF-7 cells and that of ALDH1positive cells or side population cells in FSaII cells were assessed using the methods described above. 
A

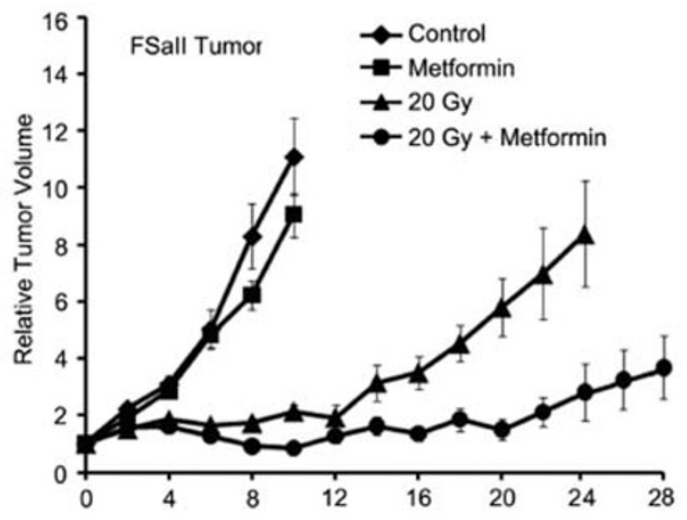

B
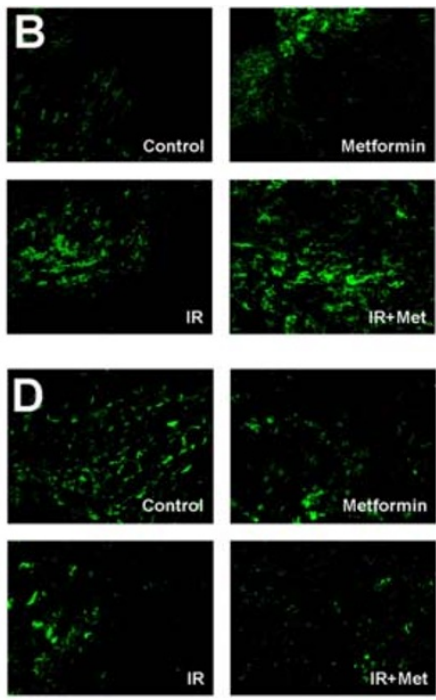
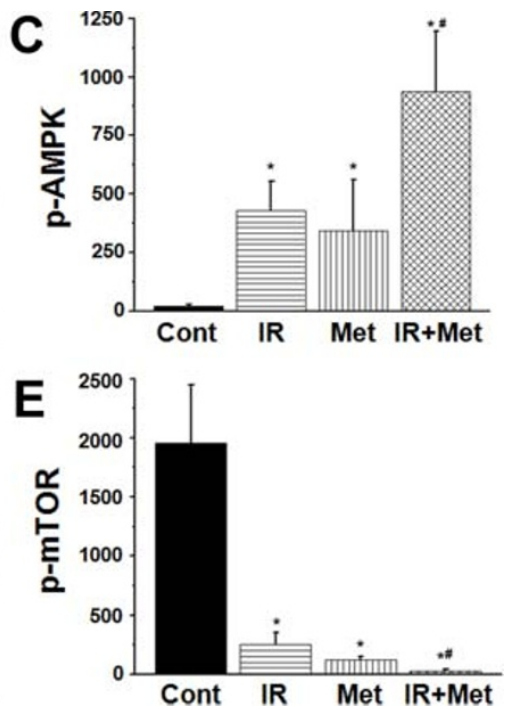

Figure 7 Growth and immunohistochemistry of FSaII tumors. (A) Tumors grown (s.c.) to $150 \mathrm{~mm}^{3}$ in the hind legs of $\mathrm{C} 3 \mathrm{H}$ mice were treated as follows. (a) Control. (b) Metformin: mice were injected i.p. twice a day with metformin at $25 \mathrm{mg} / \mathrm{kg} / \mathrm{dose}$ from Day 0. (c) Tumors were irradiated with 20 Gy of X-rays in a single exposure. (d) $20 \mathrm{~Gy}+$ Metformin: Tumors were irradiated with $20 \mathrm{~Gy}$ of X-rays in a single exposure $1 \mathrm{~h}$ after the first metformin treatment. Data points are means of 7-10 tumors \pm 1 S.E. (B-E) Immunohistological study for the expression of p-AMPK and p-mTOR in FSaII tumors. Tumors were treated with metformin and $20 \mathrm{~Gy}$ alone or combined as the tumors were treated for the tumor growth study (A), and tumors were excised on day 6 . The cross-sections were stained and quantified for p-AMPK $(B, C)$ and p-mTOR $(D, E)$. All results are expressed as mean pixel counts per image \pm standard error from 20 images derived from 3 tumors per group (magnification 200x). Representative images illustrating the average amount of staining are depicted in panels $\mathrm{B}$ and $\mathrm{D}$ for each treatment modality as indicated. ${ }^{*} P<0.001$ treatment group vs. vehicle; ${ }^{*} P<0.05$ metformin and radiation group vs. metformin alone.

Tumor growth. About $2.0 \times 10^{5} \mathrm{FSaII}$ cells in $0.05 \mathrm{~mL}$ of serum-free medium were subcutaneously injected into right hind legs of 7-8 weeks-old male C3H mice. When tumors grew to about $150 \mathrm{~mm}^{3}$ in volume, mice were randomly divided into the following four groups: (a) control, (b) metformin, (c) irradiation, (d) metformin plus irradiation. The groups (b) and (d) animals were treated twice a day with metformin by i.p. injection of $25 \mathrm{mg} / \mathrm{kg}$ drug dissolved in $0.1 \mathrm{~mL}$ saline $(50 \mathrm{mg} / \mathrm{kg} /$ day $)$. The irradiation only group (group c) received i.p injection of $0.1 \mathrm{~mL}$ saline twice a day. For the irradiation of tumors (group $\mathrm{c}$ and d), mice were anesthetized by i.p. injection of a mixture of $100 \mathrm{mg} / \mathrm{kg}$ ketamine and $10 \mathrm{mg} / \mathrm{kg}$ xylazine, the body was covered with a $2 \mathrm{~mm}$ thick lead sheet, and tumor-bearing legs were locally exposed to $20 \mathrm{~Gy}$ of radiation in a single dose with $250 \mathrm{kV}$ orthovoltage X-ray machine (Philips Medical System). Tumor diameter was measured using a caliper, and tumor volume was calculated ${ }^{53}$. At the end of the study, mice were euthanized by $\mathrm{CO}_{2}$ asphyxiation. All the animal experiments were performed following a protocol approved by the University of Minnesota Institutional Animal Care and Use Committee (Protocol number 0112A13064).

Immnunohistochemistry. Tumors treated with metformin and radiation alone or combined were excised, snap frozen in liquid nitrogen and subsequently cut in $5 \mu \mathrm{m}$ sections. Preparation and procedures for the frozen tumor sections were performed as described earlier with some slight modifications ${ }^{55-57}$. Briefly, sections were incubated for 30 min with PBS $/ 5 \%$ BSA $/ 3 \%$ FBS, and subsequently incubated with either pAMPK, or p-mTOR antibody (Cell Signaling). After one hour incubation the slides were washed thoroughly with $\mathrm{PBS} / 5 \% \mathrm{BSA} / 3 \% \mathrm{FBS}$ and the secondary antibody antirabbit IgG fluorescein iso-thiocyanate (FITC) was added (Sigma, St Louis, MO) ${ }^{56}$. One hour later, after a thorough wash, images of the sections were acquired on an Olympus IX70 Inverted Microscope at 200x magnification and digitally analyzed and differentially quantified by morphometric analysis ${ }^{57}$.

Statistics. The means of each group were compared with one-tail student's t-test. $P<0.05$ was considered significant.

1. Witters, L. A. The blooming of the french lilac. J Clin Metab. 1, 15-25 (2005).

2. Hundal, H. S., Ramlal, T., Reyes, R., Leiter, L. A. \& Klip, A. Cellular mechanism of metformin action involves glucose transporter translocation from an intracellular pool to the plasma membrane in L6 muscle cells. Endocrinology. 131, 1165-1173 (1992)

3. Dowling, R. J. O., Goodwin, R. J. \& Stambolic, V. Understanding the benefit of metformin use in cancer treatment. BMC Med. 9, 33 (2001).

4. Sahra, I. B., Marchand-Brustel, Y., Tanti, J. \& Bost, F. Metformin in cancer therapy: a new perspective for an old antidiabetic drug? Mol Cancer Ther. 9, 10921099 (2010).

5. Gonzalez-Angulo, A. M. \& Meric-Bernstam, F. Metformin: A therapeutic opportunity in breast cancer. Clin Cancer Res. 16, 1695-1700 (2010).
6. Kourelis, T. V. \& Siegel, R. D. Metformin and cancer: new applications for an old drug. Med Oncol. DOD 10.1007/s12032-011-9846-7.

7. Micic, D., Cvijovic, G., Trajkovic, V., Duntas, L. H. \& Polovina, S. Metformin: Its emerging role in oncology. Hormones. 10, 5-15 (2011).

8. Evans, J. M. M., Donnely, L. A., Emslie-Smith, A., Alessi, D. R. \& Morris, A. D. Metformin and reduced risk of cancer in diabetic patients. BMJ. 330, 1304-1305 (2005).

9. Li, D., Yeung, S. J., Hassan, M. M., Konopleva, M. \& Abbruzzese, J. L. Antidiabetic therapies affect risk of pancreatic cancer. Gastroenterology. 137, 482-488 (2009).

10. Gagnon, B., roseman, M., Kasymjanova, G., MacDonald, H. \& Kreisman, D. Protective effect of metformin in lung cancer patients. J Clin Oncol. 27, No 15s Supplement e22063 (2009).

11. Jiralerspong, S. et al. Metformin and pathologic complete response to neoadjuvant chemotherapy in diabetic patients with breast cancer. J Clin Oncol. 20, 3297-3302 (2009).

12. Dowling, R. J., Zakikhani, M., Fantus, I. G., Pollak, M. \& Sonenberg, N. Metformin inhibits mammalian target of rapamycin-dependent translation initiation in breast cancer cells. Cancer Res. 67, 10804-10812 (2007).

13. Alimova, I. N. et al. Metformin inhibits breast cancer cell growth, colony formation and induces cell cycle arrest in vitro. Cell Cycle. 8, 909-915 (2009).

14. Zakikhani, M., Dowling, R. J., Sonenberg, N. \& Pollak, M. The effects of adiponectin and metformin on prostate and colon neoplasia involve activation of AMP-Activated protein kinase. Cancer Prev Res. 1, 369-375 (2008).

15. Liu, B. et al. Metformin induces unique biological and molecular responses in triple negative breast cancer cells. Cell Cycle. 8, 2031-2040 (2009).

16. Kalender, A. et al. Metformin, independent of AMPK, inhibits mTORC1 in a Rag GTPase-dependent manner. Cell Metab. 11, 390-401 (2010).

17. Memmot, R. M., Mercado, J. R., Maier, C. R., Kawabata, S., Fox, S. D. \& Dennis, P. A. Metformin prevents tobacco carcinogen-induced lung tumorigeneisis. Cancer Prev Res. 3, 1066-1076 (2010).

18. Zhou, J. et al. Activation of the PTEN/mTOR/STAT3 pathway in breast cancer stem-like cells is required for viability and maintenance. PNAS. 41, 16158-16163 (2007).

19. Eyler, C. E., Foo, W. C., LaFiura, K. M., McLendon, R. E., Hjelmeland, A. B. \& Rich, J. N. Brain cancer stem cells display preferential sensitivity to Akt inhibition. Stem Cells. 26, 3027-3036 (2008).

20. Hill, R. \& Wu, H. PTEN, stem cells, and cancer stem cells. J Biol Chem. 284, 11755-11759 (2009).

21. Zakikhani, M., Dowling, R., Fantus, I. G., Sonenberg, N. \& Pollak, M. Metformin is an AMP Kinase-dependant growth inhibitor for breast cancer cells. Cancer Res. 66, 10269-10273 (2006)

22. Martin-Castillon, B., Vazquez-Martin, A., Oliveras-Ferraros, C. \& Menendez, J. A. Metformin and cancer: doses, mechanisms and the dandelion and hormetic phenomena. Cell Cycle. 9, 1057-1064 (2010). 
23. Karkaya, H. et al. Regulation of mammary stem/progenitor cells by PTEN/Akt/Bcatenin signaling. PLoS Biol. 7, e10000121 (2009).

24. Rocha, G. et al. Metformin amplifies chemotherapy-induced AMPK activation and antitumoral growth. Clin C ancer Res. 17, 3993-4005 (2011).

25. Sanli, T. et al. Ionizing radiation activates AMP-activated kinase (AMPK): a target for radiosensitization of human cancer cells. Int J Radiat Oncol Biol Phys. 78, 221229 (2010).

26. Rashid, A. et al. Resveratrol enhances prostate caner cell response to ionizing radiation. Modulation of the AMPK, Akt and mTOR pathway. Radiat Oncol. 6, 144-155 (2011).

27. Zannella, V. E. et al. AMPK regulates metabolism and survival in response to ionizing radiation. Radiother Oncol. 99, 293-299 (2011).

28. Al-Hajj, M., Wicha, M., Benito-Hernandes, A., Morrison, S. J. \& Clarke, M. F. Prospective identification of tumorigenic breast cancer cells. PNAS. 100, 39833988 (2003).

29. Lobo, N. A., Simono, Y., Quian, D. \& Clarke, M. F. The biology of cancer stem cells. Annu Rev Cell Dev Biol. 23, 675-699 (2007).

30. O'Brien, C. A., Kreso, A. \& Jamieson, H. M. Cancer stem cells and self-renewal. Clin Cancer Res. 16, 3113-3120 (2010).

31. Dalerba, P., Cho, R. W. \& Clarke, M. F. Cancer stem cells: Models and concept. Annu Rev Med. 58, 26-84 (2007).

32. Lou, H. \& Dean, M. Targeted therapy of cancer stem cells: the patched pathway and ABC Transporters. Oncogen. 26, 1357-1360 (2007).

33. Zhou, B. S., Zhang, H., Damelin, M., Geles, K. G., Grindley, J. C. \& Dirks, P. B. Tumor-initiating cells: challenges and opportunities for anticancer drug discovery. Nat Rev Drug Discov 8, 806-823 (2009).

34. Ma, S., Lee, T. K., Zheng, B-J., Chan, K. W. \& Guan, X-Y. CD133 ${ }^{+}$HCC cancer stem cells confer chemoresistance by preferential expression of the Akt/PKB survival pathway. Oncogene. 27, 1749-1758 (2008).

35. Frosina, G. DNA Repair and Resistance of gliomas to chemotherapy and radiotherapy. Mol Cancer Res. 7, 989-999 (2009).

36. Bao, S. et al. Glioma stem cells promote radioresistance by preferential activation of the DNA damage response. Nature. 444, 756-760 (2006).

37. Phillips, T. M., McBride, W. H. \& Pajonk, F. The Response of CD24 ${ }^{-/ \text {low }} / \mathrm{CD} 44^{+}$ breast cancer initiating cells to radiation. J Natl Cancer Inst. 98, 1777-1785 (2006).

38. Baumann, M., Krause, M. \& Hill, R. Exploring the role of cancer stem cells in radioresistance. Nat Rev Cancer. 8, 545-554 (2008).

39. Hirsch, H. A., Iliopoulos, D., Tsichlis, P. N. \& Struhl, K. Metformin selectively targets cancer stem cells and acts together with chemotherapy to block tumor growth and prolong remission. Cancer Res. 69, 7507-7511 (2009).

40. Iliopoulos, D., Hirsch, H. A. \& Struhl, K. Metformin decreases the dose of chemotherapy for prolonging tumor remission in mouse xenografts involving multiple cancer cell types. Cancer Res. 71, 3196-3201 (2011).

41. Vazquerz-Martin, A., Oliveras-Ferraros, C., Barco, S. D., Martin-Castillo, B. \& Menendez, J. A. The anti-diabetic drug metformin suppresses self-renewal and proliferation of trastuzumbab-resistant tumor-initiating breast cancer stem cells. Breast Cancer Res Treat. 126, 355-364 (2011).

42. Choi, B. H. et al. Response of cancer stem cells to ionizing radiation and metformin alone and combined. Abstract \# PS3.49, 56 $6^{\text {th }}$ Annual Meeting of the Radiation Research Society, Grand Wailea Resort Hotel and Spa, Maui, Hawaii. Sept $25^{\text {th }}-29^{\text {th }}(2010)$

43. Song, C. W. et al. Metformin increases the response of tumors to radiotherapy by eliminating cancer stem cells. Abstract \# PS3.57. $56^{\text {th }}$ Annual Meeting of the Radiation Research Society, Grand Wailea Resort Hotel and Spa, Maui, Hawaii. Sept $25^{\text {th }}-29^{\text {th }}(2010)$

44. Charafe-Jauffret, E., Ginesteir, C. \& Birnbaum, D. Breast cancer stem cells: tools and models to rely on. BMC Cancer. 9, 1471-2407 (2009).

45. Ginestier, C. et al. ALDH1 is a marker of normal and malignant human mammary stem cells and predictor of poor clinical outcome. Cell Stem Cell. 1, 555-597 (2007).
46. Li, Y. et al. Sulforaphane, a dietary component of broccoli/broccoli sprouts, inhibits breast cancer stem cells. Clin Cancer Res. 16, 2580-2590 (2010).

47. Levina, V., Marrangoni, A. M., DeMarco, R., Gorelik, E. \& Lokshin, A. E. Drug selected human lung cancer stem cells: cytokine network, tumorigenic and metastatic properties. PLoS One. 3, e3007 (2008).

48. Nagata, Y. et al. Effect of rapamycin, an mTOR inhibitor, on radiation sensitivity of lung cancer cells having different p53 gene status. Int J Oncol. 37, 1001-1010 (2010).

49. Shinohaa, E. T. et al. Enhanced radiation damage of tumor vasculature by mTOR inhibitiors. Oncogen. 24, 5414-5422 (2005).

50. Braunstein, S., Badura, M. L., Xi, Q., Formenti, S. C. \& Schneider, R. J. Regulation of protein sysnthesis by ionizing radiation. Mol Cell Biol. 29, 5645-5656 (2009).

51. Buzzai, M. et al. Systemic treatment with the antidiabetic drug metformin selectively impairs p53-deficient tumor cell growth. Cancer Res. 67, 6745-6752 (2007).

52. Kisfalvi, K., Eibl, G., Sinnett-Smith, J. \& Rozengurt, E. Metformin disrupts crosstalk between $\mathrm{G}$ protein-coupled receptor and insulin receptor signaling systems and inhibits pancreatic cancer growth. Cancer Res. 69, 6539-6545 (2009).

53. Rattan, R., Graham, R. P., Maguire, J. L., Giri, S. \& Shridhar V. Metformin suppresses ovarian cancer growth and metastasis with enhancement of cisplatin cytotoxicity in vivo. Neolasia. 13, 483-491 (2011).

54. Park, H. et al. Susceptibility of cancer cells to B-Lapachone is enhanced by ionizing radiation. Int J Radiat Oncol Biol Phys. 61, 212-219 (2005).

55. Dings, R. et al. Tumour thermotolerance, a physiological phenomenon involving vessel normalisation. Int J Hyperthermia. 27, 42-52 (2011).

56. Dings, R. et al. Inhibiting tumor growth by targeting tumor vasculature with galectin-1 antagonist anginex conjugated to the cytotoxic acylfulvene, 6-hydroxylpropylacylfulvene. Bioconjug Chem. 21, 20-7 (2010).

57. Dings, R. et al. Scheduling of radiation with angiogenesis inhibitors Anginex and Avastin improves therapeutic outcome via vessel normalization. Clin Cancer Res. 13, 3395-3402 (2007)

\section{Acknowledgement}

We greatly thank Drs. Seymour Levitt, Kathryn Dusenbery and Douglas Yee for their interest in the present work and encouragement. This work was supported by Joseph Wargo Fund from the Minnesota Medical Foundation, Komen for the Cure Fund from the University of Minnesota Cancer Center, R\&D Program of KOSEF (2009-0093747 and 2011-0015230) and Korea Health 21 R\&D Project (A062254).

\section{Author contributions}

HP and CS wrote the main manuscript text, JP and TS prepared figures 1 and 6, HL and BC prepared figures 2, 3 and 5, BW prepared figures 4 and 6 and RD prepared figure 7 . All authors reviewed the manuscript.

\section{Additional information}

Supplementary information accompanies this paper at http://www.nature.com/ scientificreports

Competing financial interest: The authors declare no competing financial interests.

License: This work is licensed under a Creative Commons

Attribution-NonCommercial-ShareAlike 3.0 Unported License. To view a copy of this license, visit http://creativecommons.org/licenses/by-nc-sa/3.0/

How to cite this article: Song, C.W. et al. Metformin kills and radiosensitizes cancer cells and preferentially kills cancer stem cells. Sci. Rep. 2, 362; DOI:10.1038/srep00362 (2012). 